\title{
T.W. Schultz and the Human-Capital Approach to Entrepreneurship*
}

\section{Peter G. Klein and Michael L. Cook}

T. W. Schultz's theory of entrepreneurship is among his least known,

but most interesting, contributions. While entrepreneurship is increasingly recognized as important for economic organization and development, it is not a major component of the economist's day-to-day toolkit. This paper describes Schultz's approach and compares it to other concepts of entrepreneurship in economics and management.

\section{Entrepreneurship and Economic Organization}

Because entrepreneurs in many ways personify market forces, one might expect them to be the central figures in economics. Similarly, because most entrepreneurial ventures somehow involve a firm, entrepreneurship would seem to be a core element of the economics of organization (represented, for example, by Milgrom and Roberts). However, entrepreneurship has been largely neglected by modern economists. Entrepreneurship is invoked in an ad hoc fashion, when needed, to explain aspects of firm organization (Knight), economic development (Schumpeter 1911), market dynamics (Kirzner), and leadership (Witt). Moreover, while many business schools feature entrepreneurship curricula, the phenomenon under investigation is usually small-business management, the study of routine management tasks, relationships with venture capitalists and other sources of external finance, product development, marketing, and so on.

Peter G. Klein is an assistant professor in the Department of Agricultural Economics and Associate Director of the Contracting and Organizations Research Institute at the University of Missouri.

- Michael L. Cook is Robert D. Partridge chair in the Department of Agricultural Economics at the University of Missouri.

\footnotetext{
*This paper was presented at the Principal Paper session, "AAEA Invited Paper Session in Memory of T.W. Schultz," Allied Social Sciences Association annual meeting, Boston, January 6-8, 2006.
}

The articles in these sessions are not subject to the journal's standard refereeing process. 
In the academic management literature, entrepreneurship is often associated with boldness, daring, imagination, or creativity (Begley and Boyd; Chandler and Jansen; Lumpkin and Dess). These accounts emphasize the personal, psychological characteristics of the entrepreneur. In this conception, entrepreneurship is not a necessary component of all human decision making, but a specialized activity that some individuals are particularly well-equipped to perform, and one that can presumably be hired on the market like any other consulting service. Another strand of literature, incorporating insights from economics, psychology, and sociology and leaning heavily on Max Weber, associates entrepreneurship with leadership (Witt). Entrepreneurs, in this view, specialize in communication-the ability to articulate a plan, a set of rules, or a broader vision, and impose it on others. The successful entrepreneur excels at communicating these models to others, who come to share the entrepreneur's vision (and become his followers).

While economists have not completely ignored the entrepreneur, there is little consensus about how entrepreneurship should be modeled and incorporated into economic theory. Indeed, the most important contributions to the economic theory of entrepreneurship have generally been viewed as interesting, but idiosyncratic insights that do not easily generalize to other contexts and economic problems. Schumpeter's well-known concept of the entrepreneur as innovator is a prime example. Schumpeter's entrepreneur introduces "new combinations" - new products, production methods, markets, sources of supply, or industrial combinations-shaking the economy out of its previous equilibrium through a process Schumpeter termed "creative destruction."

Realizing that the entrepreneur has no place in the general-equilibrium system of Walras, Schumpeter $(1911,1939)$ gave the entrepreneur a role as the source of economic change. "[I]n capitalist reality as distinguished from its textbook picture, it is not [price] competition which counts but the competition from the new commodity, the new technology, the new source of supply, the new type of organization ... competition which commands a decisive cost or quality advantage and which strikes not at the margins of profits and the outputs of existing firms but at their foundations and their very lives" (Schumpeter, 1942, p. 84).

Schumpeter carefully distinguished entrepreneurs from capitalists. While entrepreneurs could be managers or owners of firms, they are more likely to be independent contractors or craftsmen. In Schumpeter's conception, "people act as entrepreneurs only when they actually carry out new combinations, and lose the character of entrepreneurs as soon as they have built up their business, after which they settle down to running it as other people run their businesses" (Ekelund and Hébert, p. 569). Moreover, because Schumpeterian entrepreneurship is sui generis, independent of its environment, the nature and structure of the firm does not affect the level of entrepreneurship. Corporate R\&D budgets, along with organizational structures that encourage managerial commitment to innovation (Hoskisson and Hitt), have little to do with Schumpeterian entrepreneurship per se.

Kirzner's (1973) concept of entrepreneurship as "alertness" to profit opportunities is another well-known economics approach. The simplest case is that of the arbitrageur, who discovers a discrepancy in present prices that can be 
exploited for financial gain. In a more typical case, the entrepreneur is alert to a new product or a superior production process and steps in to fill this market gap before others. Success, in this view, comes not from following a well-specified maximization problem, but from having some insight that no one else has, a process that cannot be modeled as an optimization problem. As in Schumpeter's vision, Kirzner's entrepreneurs do not own capital; they need to be only alert to profit opportunities. Because they own no assets, they bear no uncertainty, and hence cannot earn losses; failure to discover an existing profit opportunity is the worst that can happen to an entrepreneur. For these reasons, the link between Kirznerian entrepreneurship and the theory of firm organization is weak. Owners, managers, employees, and independent contractors can be alert to new profit opportunities; Kirzner's entrepreneur does not need a firm to exercise his function in the economy.

An alternative to the foregoing accounts is that entrepreneurship consists of judgmental decision making under conditions of uncertainty. Judgment refers primarily to business decision making when the range of possible future outcomes, let alone the likelihood of individual outcomes, is generally unknown (what Knight terms uncertainty, rather than mere probabilistic risk). Judgment is distinct from boldness, innovation, alertness, and leadership. Judgment must be exercised in mundane circumstances, for ongoing operations as well as new ventures.

Knight introduces judgment to link profit and the firm to uncertainty. Entrepreneurship represents judgment that cannot be assessed in terms of its marginal product and which cannot, accordingly, be paid a wage (Knight, p. 311). In other words, there is no market for the judgment that entrepreneurs rely on, and therefore, exercising judgment requires the person with judgment to start a firm. Judgment thus implies asset ownership, for judgmental decision making is ultimately decision making about the employment of resources. An entrepreneur without capital goods is, in Knight's sense, no entrepreneur (Foss and Klein).

\section{Schultz's Theory of Entrepreneurship: The Human-Capital Approach}

Schultz $(1975,1979,1982)$, like Schumpeter, works in the Walrasian tradition. However, unlike Walras and Schumpeter, Schultz recognizes that markets do not automatically and instantaneously regain equilibrium following an exogenous shock. "[R]egaining equilibrium takes time, and how people proceed over time depends on their efficiency in responding to any given disequilibrium and on the costs and returns of the sequence of adjustments available to them" (Schultz, 1975, p. 829). Surprisingly, economists have devoted little attention to this problem. ${ }^{1}$ Even Schumpeter, who saw economic progress as the result of disruptions to existing equilibrium states, assumed that equilibrium is quickly regained following such a disruption. Schultz, by contrast, took innovation as given, and focused on how economic agents adjust to exogenous shocks. An example is farmers in a developing economy. Such people must "deal with a sequence of changes in economic conditions, which are in general, not of their 
own making because they originate mainly out of the activities of people other than farm people. For this reason, Schumpeter's theory of economic development is far from sufficient to explain most of these changes" (Schultz 1975, p. 832). Moreover, the atomistic nature of agriculture and the unique aspects of farm production generate problems of collective action and by-product behavior (Olson), making such adjustments more difficult.

In Schultz's formulation, entrepreneurship is the ability to adjust or reallocate resources in response to changing circumstances. As such, entrepreneurship is an aspect of all human behavior, not a unique function performed by a class of specialists. "No matter what part of the economy is being investigated, we observe that people are consciously reallocating their resources in response to changes in economic conditions" (Schultz, 1979, p. 2). Businessmen, farmers, housewives, students, and even university presidents, deans, and research directors make Schultz's (1979) list of entrepreneurs. ${ }^{2}$

Somewhat paradoxically, the degree to which entrepreneurship is manifested in a society is itself determined by supply and demand. ${ }^{3}$ The demand for entrepreneurial services is given by the expected gains from adjusting one's resources in the face of the disequilibrium, itself a function of some characteristics of that disequilibrium. The supply of entrepreneurial capacities is given by agents' abilities to perceive and exploit opportunities. Like any economic good, entrepreneurship is valuable and scarce (Schultz, 1979, p. 6). Knight and Kirzner treat entrepreneurship as "extra-economic," meaning that it is the driving force behind the pricing process, but is not itself traded and priced on the market. Schultz (1979) insists that entrepreneurial ability, like other services available for hire, is a resource with a market price and quantity, though he did not develop this insight into a fully specified theory of the supply of and demand for entrepreneurship.

Schultz conceives entrepreneurial ability as a form of human capital. Like other forms of human capital, this ability can be increased through education, training, experience, health care, and so on. While education and other human-capital investments also lead to improvements in technical and allocative efficiency, Schultz argues that efficiency improvements cannot account for all of the effects of education on economic performance, particularly in agricultural communities during periods of modernization. Increased abilities to adjust to change, for instance by adopting new technology and organizational practices, explain at least part of the returns to education. Moreover, an economy's aggregate stock of entrepreneurial ability can also be increased by the immigration of people with particular entrepreneurial experiences and skills (presumably in response to increased opportunities for entrepreneurial gain).

\section{Discussion and Implications}

While Schultz's human-capital approach to entrepreneurship has received little attention among economists, it offers several potential advantages over the better-known concepts mentioned above. First, Schultz's approach offers more testable implications; for instance, he shows how background and environmental conditions can be used to derive a supply function for entrepreneurship (which Schumpeter explicitly frowned upon). Second, Schultz 
emphasizes the temporal aspect of entrepreneurial adjustment, particularly important for agricultural production in which temporal specificities loom large. Third, the concept of a market for entrepreneurial services has rich implications for economic organization; for example, under what circumstances can resource owners hire out for entrepreneurial services, and when must they coordinate their own adjustments to disequilibrium conditions? What kinds of contracts effectively govern the exchange of entrepreneurship?

However, Schultz's approach suffers from several weaknesses as well. Most important, Schultz does not really grapple with the implications of disequilibrium, but instead presents what is essentially an equilibrium model of technology adoption. It has long been recognized that technological innovations do not diffuse evenly throughout an economy, but instead are adopted at different rates in different markets. Rosenberg observes that "in the history of diffusion of many innovations, one cannot help being struck by two characteristics of the diffusion process: its apparent overall slowness on the one hand, and the wide variations in the rates of acceptance of different inventions, on the other." As modeled by Hall and Khan, for example, an individual producer's decision to adopt a new technology depends on the ratio of short-term transition costs (particularly learning) and the long-term benefits of using the superior method of production. When these future benefits are uncertain and agents have different expectations about them, there is an option value to deferring the decision to adopt. Increased uncertainty and heterogeneity of expectations thus explains the variation in adoption rates across technologies and markets.

Technological innovation can diffuse slowly and unevenly for other reasons. First, there is a need for complementary organizational structures. Chandler $(1962,1977)$ shows how the rise of large, vertically integrated industrial enterprises during the early twentieth century gave manufacturers the ability and incentives to develop and deploy new technologies. More recently, new information-management technologies (supply-chain management and distribution systems) have given power to large retailers, whose procurement systems drive the entire vertical process of production. Second, complementary marketing and branding strategies must be developed. ${ }^{4}$

In short, especially when applied to his preferred example-agricultural producers' responses to technological change-Schultz's concept of entrepreneurship looks very much like conventional equilibrium models of the diffusion of innovation. Thus, while Schultz shares with Knight and Kirzner (and, to a lesser degree, Schumpeter) a desire to go beyond comparative statics, to provide an economic role for human creativity, and to highlight the entrepreneurial aspect of all human behavior, his formal conception of entrepreneurship differs sharply from theirs. Knight, Schumpeter, and Kirzner view entrepreneurship as a phenomenon that cannot be understood as the result of an optimization problem..$^{5}$ Moreover, Schultz also portrays entrepreneurship as a relatively passive activity, a secondary response to exogenous changes in the economic environment, without explaining the drivers of these changes. Finally, Schultz cites the substantial literature documenting the returns to education and other forms of human capital as evidence for his concept of entrepreneurship. But it is not clear that these returns derive from the ability to 
deal with disequilibria, rather than simply greater efficiency at predefined tasks.

Still, the human-capital approach to entrepreneurship holds considerable promise for students of economic organization and development, particularly in agriculture, the industry Schultz knew best. This paper provides only a preliminary, exploratory sketch of Schultz's ideas on this subject. While Schultz penned many lines on human capital, he explicitly compares his approach to entrepreneurship with those of Knight, Schumpeter, and Kirzner in only a few papers (particularly Schultz 1975, 1979, 1982). We look forward to future work providing a more comprehensive assessment of these important contributions.

\section{Endnotes}

\footnotetext{
${ }^{1}$ Prominent exceptions include Arrow; Fisher; and Littlechild and Owen.

${ }^{2}$ Holmes and Schmitz, by contrast, develop a model inspired by Schultz in which a division of entrepreneurial labor, with some individuals specializing in entrepreneurial action, emerges.

${ }^{3}$ The paradox is that the quantity of entrepreneurship - the ability to deal with disequilibria-is itself modeled as the equilibrium outcome of a supply-and-demand analysis!

${ }^{4}$ See James, Klein, and Sykuta for more on the adoption of organizational innovation, particularly in agriculture.

${ }^{5}$ Kirzner, for example, explicitly distinguishes his entrepreneurs from what he calls "Robbinsian maximizers," agents whose behavior can be explained using the standard tools of constrained maximization. See Garrison for more on Kirzner is this regard.
}

\section{References}

Arrow, K. "Toward a Theory of Price Adjustment." In The Allocation of Economic Resources: Essays in Honor of Bernard Francis Haley, M. Abramovitz, et al., eds. Stanford: Stanford University Press, 1959.

Begley, T., and D. Boyd. "Psychological Characteristics Associated with Performance in Entrepreneurial Firms and Smaller Businesses." J. Bus. Venturing 2(1987):79-93.

Chandler, A.D., Jr. Strategy and Structure: Chapters in the History of Industrial Enterprise. Cambridge MA: MIT Press, 1962.

—. The Visible Hand: The Managerial Revolution in American Business. Cambridge MA: Harvard University Press, 1977.

Chandler, G.N., and E. Jansen. “The Founder's Self-Assessed Competence and Venture Performance." J. Bus. Venturing 7(1992):223-36.

Ekelund, R.B., Jr., and R.F. Hébert. A History of Economic Thought and Method, 3rd edition. New York: McGraw-Hill, 1990.

Fisher, F.M. Disequilibrium Foundations of Equilibrium Economics. Cambridge: Cambridge University Press, 1983.

Foss, N.J., and P.G. Klein. "Entrepreneurship and the Economic Theory of the Firm: Any Gains from Trade?" In Handbook of Entrepreneurship Research: Disciplinary Perspectives, R. Agarwal, S.A. Alvarez, and O. Sorenson, eds. Dordrecht: Springer, 2005.

Garrison, R.W. "Equilibrium and Entrepreneurship." Adv Austrian Econ. 2(1995):67-78.

Hall, B.H., and B. Khan. "Adoption of New Technology." In New Economy Handbook, D. Jones, ed. New York: Elsevier, 2003.

Holmes, T.J., and J.A. Schmitz, Jr. "A Theory of Entrepreneurship and Its Application to the Study of Business Transfers." J. Pol. Eco. 98(2001):265-94.

Hoskisson, R.E., and M.A. Hitt. Downscoping: How to Tame the Diversified Firm. New York: Oxford University Press, 1994.

James, H.S., Jr., P.G. Klein, and M.E. Sykuta. “Markets, Contracts, or Integration? The Adoption, Diffusion, and Evolution of Organizational Form." Working paper, Contracting and Organizations Research Institute, University of Missouri, 2005.

Kirzner, I.M. Competition and Entrepreneurship. Chicago: University of Chicago Press, 1973.

Knight, F.H. Risk, Uncertainty, and Profit. New York: August M. Kelley, 1921.

Littlechild, S.C., and G. Owen. "An Austrian Model of the Entrepreneurial Market Process." J. Econ. Theory 23(1980):361-79. 
Lumpkin, G.T., and G.G. Dess. "Clarifying the Entrepreneurial Orientation Construct and Linking it to Performance." Acad. Manage. Rev. 21(1996):135-72.

Milgrom, P., and J. Roberts. Economics, Organization, and Management. Englewood Cliffs NJ: Prentice-Hall, 1992.

Olson, M. Logic of Collective Action: Public Goods and the Theory of Groups, Revised edition. Cambridge MA: Harvard University Press, 1971.

Rosenberg, N. "Factors Affecting the Diffusion of Technology." Explor. Econ. Hist. 10, no. 1 (1972):3-33.

Schultz, T.W. "The Value of the Ability to Deal with Disequilibria." J. Econ. Lit. 13, no. 3(September 1975):827-46.

. "Concepts of Entrepreneurship and Agricultural Research." Kaldor Memorial Lecture, Iowa State University, October 1979.

. "Investment in Entrepreneurial Ability." Scand. J. Econ. 82, no. 4(1982):437-48.

Schumpeter, J.A. The Theory of Economic Development: An Inquiry into Profits, Capital, Credit, Interest, and the Business Cycle. Translated by Redvers Opie. Cambridge, MA: Harvard University Press, [1911], 1934.

- Business Cycles: A Theoretical, Historical and Statistical Analysis of the Capitalist Process. New York: McGraw-Hill, 1939.

Capitalism, Socialism, and Democracy. New York: Harper \& Row, 1942.

Witt, U. "Imagination and Leadership: the Neglected Dimension of an Evolutionary Theory of the Firm." J. Econ. Behav. Org. 35(1988):161-77. 